\title{
РАЗВИТИЕ ЗАКОНОДАТЕЛЬСТВА ОБ ОТВЕТСТВЕННОСТИ ЗА ЭКСТРЕМИЗМ И ТЕРРОРИЗМ В ПЕРИОД ДЕЙСТВИЯ УГОЛОВНОГО КОДЕКСА РСФСР 1960 ГОДА
}

\begin{abstract}
Аннотация: Статья посвящена анализу законодательства об ответственности за экстремизм и терроризм в период действия УК РСФСР 1960 г. Констатируется, что началом нового этапа развития уголовного законодательства об ответственности за экстремизм и терроризм, стало принятие в 1958 году Закона СССР «Об уголовной ответственности за государственные преступления». Автором проведен сравнительный анализ соответствующих положений УК РСФСР 1926 г. в сфере противодействия контрреволюичонным преступлениям и особо для Союза ССР опасным преступлениям против порядка управления и положений УК РСФСР 1960 г. в сфере противодействия государственным преступлениям. Методологической основой настоящего исследования служат базовые положения диалектического метода познания явлений и процессов объективной действительности. Также в работе использовались современные общенаучные, частнонаучные и специальные методы исследования: логико-юридический, сравнительно-правовой, системно-структурного анализа и др. Автором сделан вывод, что регламентация в Законе 1958 г. ответственности за разновидовые преступления не способствовала выработке общего определения понятия иного государственного преступления. В связи с этим в юридической литературе советского периода отсутствует единое мнение по вопросу, что следует под таковым понимать. Констатируется, что именно по этой же причине аналогичные сложности возникают и при выработке научного понятия «экстремизм (экстремистская деятельность)». В первоначальной редакции ст. 74 УК 1960 г. впервые в истории уголовного законодательства России была установлена ответственность за дискриминацию по признакам расы и (или) национальности. Вместе с тем в описании объективной стороны данного преступления не нашло отражение указание на агитацию и пропаганду, направленные к разжиганию религиозной вражды или розни, имевшее место в УК 1926 г. Автором данное решение законодателя оценивается как определенный шаг назад.
\end{abstract}

Ключевые слова: Экстремизм, терроризм, возбуждение вражды, Советская власть, государственные преступления, дискриминация, пропаганда, террористический акт, раса, национальность.

Abstract: This article is dedicated to the analysis of legislation on responsibility for extremism and terrorism during the validity time of the Criminal Code of RSFSR of 1960. It is claimed that the beginning of a new stage of criminal legislation became the introduction in 1058 of the USSR Law "On Criminal Responsibility for State Crimes". The author conducts a comparative analysis of the corresponding positions of 1926 RSFSR Criminal Code in the area of counteraction against counterrevolutionary crimes and against the order of government and positions of the Criminal Code of 1960 in the sphere of counteraction against state crimes, especially dangerous for the Soviet Union. The author concludes that regulation on responsibility for various crimes in the Law of 1958 did not contribute to the development of a general definition of the notion of the other state crime. Due to this fact, there is no unified opinion within the Soviet legal literature related to the question of what should be understood under a state crime. It is stated that namely for this reason the similar difficulties emerge in development of a scientific definition of "extremism (extremist activity)". The responsibility for racial and (or) ethnic discrimination first in history of the Russian criminal legislation, has been established in the original version of the Article 74 of the 1960 Criminal Code. At the same time, in describing the objective side of such crime, there was no indication towards agitation or propaganda aimed at instigation on religious animosity, as in the Criminal Code of 1926. The author considers such legislative solution as a certain step back.

Keywords: Discrimination, state crimes, Soviet Authority, instigation of animosity, terrorism, extremism, propaganda, act of terrorism, race, nationality. 


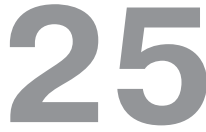

декабря 1958 г. Верховным Советом СССР принят Закон «Об уголовной ответственности за государственные преступления» (далее - Закон СССР 1958 г.; Закон 1958 г.). Его принятие стало началом нового этапа развития законодательства об ответственности за преступления, содержащие признаки экстремистской деятельности в современном ее понимании. Необходимо отметить, что данный Закон был полностью включен в уголовные кодексы всех союзных республик. Не стал исключением и новый Уголовный кодекс РСФСР, принятый 27 ноября 1960 г. (далее - УК 1960 г.).

Структура Закона 1958 г., а впоследствии и главы первой УК 1960 г., позволяет говорить о двух группах государственных преступлениях:

- особо опасные государственные преступления (одноименный раздел первый УК 1960 г. (ст.ст. 64-73)) - первая группа;

- иные государственные преступления (одноименный раздел второй УК 1960 г. (ст. ст. 74-88)) - вторая группа.

Анализ Закона 1958 г. свидетельствует о том, что законодатель оперирует термином «государственные преступления», а понятие контрреволюционного преступления было исключено. В Законе термин «государственные преступления» имел обобщающее значение и его содержание не раскрывалось. Закон 1958 г. не содержал и общих определений понятий «особо опасное государственное преступление» и «иное государственное преступление». Необходимо отметить, что в науке уголовного права предпринимались попытки выработать определения данным понятиям. Изучение юридической литературы советского периода позволяет сделать вывод об отсутствии единства мнений по вопросу дефиниции «особо опасное государственное преступление», что было обусловлено расхождением авторов в определении субъективных и объективных признаков данного вида преступлений. Однако, несмотря на это в принципиальных позициях эти определения совпадали. Наиболее развернутым, представляется, определение, в котором особо опасным государственным преступлением предлагалось признавать «предусмотренное общесоюзным уголовным законодательством общественно опасное деяние, умышленно направленное в ущерб общественному строю СССР» [1, с. 12].

Следует отметить, что во втором разделе Закона 1958 г. регламентировалась ответственность за разновидовые преступления. Как ранее нами отмечалось [2, с. 398], данный подход был реализован при формировании ответственности за контрреволюционные преступления. Указанное обстоятельство не способствовало выработке общего определения понятия иного государственного преступления. В связи с этим в юридической литературе советского периода отсутствует единое мнение по вопросу, что следует под таковым понимать. Анализ определений понятия «иное государственное преступление», выработанных наукой уголовного права, позволяет сделать вывод, что в большинстве своем ученые пытались раскрыть его содержание, исходя из непосредственного объекта преступлений, включенных в соответствующий раздел Закона 1958 г.

Целью настоящего исследования не является выработка данного понятия и систематизация преступлений, включенных в Закон СССР 1958 г. Вместе с тем необходимо отметить, что аналогичные сложности возникают и при выработке научного понятия «экстремизм» [3, с. 158-162]. В связи с этим, представляется целесообразным привести пример выработанного наукой уголовного права определения понятия «иное государственное преступление». Под иным государственным преступлением предлагалось понимать - «предусмотренное общесоюзным уголовным законом общественно опасное деяние, умышленно или неосторожно посягающее на основы государственного управления СССР в наиболее важных сферах жизнедеятельности страны; в области национальных отношений, обороны страны, денежно-кредитных отношений внешней торговли, охраны общественного порядка и общественной безопасности» [4, с. 14].

Как ранее было отмечено, в новом УК РСФСР, как и в предыдущем УК, Особенная часть открывалась главой «Государственные преступления», в которой устанавливалась ответственность за соответствующие преступления. Содержание понятия «государственные преступления»в УК не раскрывалось, а его смысловая нагрузка заключалась, как и в УК 1926 г., в объединении в одной главе преступлений, признаваемых законодателем государственными.

Сравнительный анализ положений УК 1960 г. и УК 1926 г., относящихся к теме настоящего исследования, позволяет сделать следующие выводы:

1) В УК 1960 г. изменено количество статей об особо опасных государственных преступлениях с 14 до 10. Кроме того каждая статья получила свое наименование. В разделе первом УК 1960 г. 
появились новые нормы, регламентирующие ответственность за пропаганду войны и террористический акт против представителя иностранного государства. Однако следует отметить, что в вопросе ответственности за преступную организационную деятельность, направленную на совершение особо опасных государственных преступлений, УК 1960 г. сохранил преемственность с УК 1926 г., выразившуюся, в уравнивании ответственности участников и организаторов преступлений.

2) Изменена диспозиция статьи, устанавливающей ответственность за террористический акт (ст. 66 УК 1960 г.).

Во-первых, формулировка деяния «совершение террористических актов»в ст. 58.8 УК 1926 г. в соответствующей статье УК 1960 г. была уточнена и заменена на понятие «убийство» и «причинение тяжкого телесного повреждения» (ч. 1 и ч. 2 ст. 66 УК РСФСР 1960 г. соответственно).

Во-вторых, в диспозиции ст. 66 УК 1960 г. качестве обязательного признака рассматриваемого состава преступления выступала цель: совершение деяний, указанных в диспозиции ст. 66 УК, в отношении государственного или общественного деятеля или представителя власти в связи с его государственной или общественной деятельностью, с целью подрыва или ослабления Советской власти». Из текста диспозиции ст. 66 УК 1960 г. следует, что террористический акт относился к особо опасным государственным преступлениям только в случае, если он был персонифицирован и совершен с целью подрыва или ослабления Советской власти. Следует отметить, что в 1994 г. в ст. 66 УК были внесены изменения, связанные с изменением политической системы в стране. В редакции диспозиции данной статьи цель совершения перечисленных в ней деяний была изменена на политические мотивы.

Таким образом, неотъемлемым признаком объективной стороны преступления, предусмотренного ст. 66 УК 1960 г., являлось то, что совершение деяний, предусмотренных в диспозиции данной нормы, в отношении указанных в ней лиц, должно находиться в обязательной связи с их государственной или общественной деятельностью. Следует оговориться, что речь идет именно о деянии, а не о действии, так как террористический акт мог совершаться и путем бездействия. Например, «врач, сознательно не оказывающий помощи, допускает гибель представителя власти, государственного или общественного деятеля, преследуя цель подрыва или ослабления Советской власти» [5, с. 110-111].
Указанные изменения позволяют констатировать, что формулировка статьи, регламентирующей ответственность за террористический акт в УК 1960 г., с точки зрения законодательной техники, была довольно четкой и полной. В ней довольно точно давалось понятие террористического акта, и были указаны признаки объективной и субъективной стороны преступления. В свою очередь это позволяло максимально исключить возможность применения при квалификации данного деяния смежных с ним норм [6].

Еще одна отличительная особенность ст. 66 УК 1960 г. заключалась в том, что в ней не устанавливалась ответственность за участие в совершении террористических актов. Представляется, что участие в совершении террористического акта подлежало квалификации по ст. 17 и соответствующей части ст. 66 УК 1960 г., т.е. применялись правила квалификации преступлений, совершаемых в соучастии.

3) В УК 1960 г. не была включена статья, вводившая принцип обратной силы уголовного закона, и устанавливающая ответственность за «активную борьбу против рабочего класса и революционного движения, <..> при царском строе или у контрреволюционных правительств в период гражданской войны». Безусловно, данное решение законодателя в отношении данной нормы можно было назвать позитивным и прогрессивным. Однако, представляется, что статья, отражавшая определенные исторические условия развития Советской власти, и обусловленная классовой борьбой Советского государства, не нашла места в УК 1960 г., по причине того, что она попросту «изжила» себя. Представляется, что данная норма была признана естественно умершей нормой.

4) Важным изменениям была подвергнута статья, регламентирующая ответственность за посягательство на межнациональные отношения. Ст. 11 Закона 1958 г. со значительными изменениями воспроизводила ст. 21 Положения о преступлениях государственных 1927 г. В ней устанавливалась ответственность за пропаганду или агитацию с целью возбуждения расовой или национальной вражды или розни, а равно за прямое или косвенное ограничение прав или установление прямых или косвенных преимуществ граждан в зависимости от их расовой или национальной принадлежности. Именно в таком виде данная норма была включена в УК 1960 г. ст. 74. Если провести параллель с современным законодательством, то можно сделать вывод, что 
ст. 74 УК 1960 г. представляет собой симбиоз ст. 136 «Нарушение равенства прав и свобод человека и гражданина» и ст. 282 «Возбуждение ненависти либо вражды, а равно унижение человеческого достоинства»ныне действующего УК РФ.

Выделим отличительные особенности формулировки ст. 74 УК 1960 г. в сравнении со ст. 59.7 УК 1926 г.:

Во-первых, определен непосредственный объект преступления, предусмотренного ст. 74 УК 1960 г., - национальное и расовое равноправие.

Во-вторых, изменена объективная сторона рассматриваемого преступления путем:

а) исключения из ее описания указания на агитацию и пропаганду, направленных к разжиганию религиозной вражды или розни. Одновременно криминализированы пропаганда и агитация, направленные к разжиганию расовой вражды или розни;

б) исключения такой формы объективной стороны преступления как распространение или изготовление и хранение литературы с соответствующим содержанием. Вместе с тем нельзя сказать, что данные деяния были декриминализированы. Представляется, что распространение литературы с соответствующим содержанием входило в объем понятий «пропаганда»и «агитация» [2, с. 399]. В свою очередь изготовление и хранение литературы того же характера являются приготовлением к преступлению, предусмотренному ст. 74 УК 1960 г. Из текста ст. 15 в первоначальной редакции УК 1960 г. следует, что уголовная ответственность наступала за приготовление к любому преступлению. В соответствии с ч. 3 данной статьи наказание за приготовление к преступлению и за покушение на преступление назначалось по статье Особенной части УК, предусматривающей ответственность за соответствующее преступление;

в) ее расширения за счет включения альтернативных способов совершения рассматриваемого преступления:

- прямое или косвенное ограничение прав граждан в зависимости от их расовой или национальной принадлежности;

- установление прямых или косвенных преимуществ граждан по тем же основаниям.

Таким образом, впервые в истории уголовного законодательства России была установлена ответственность за дискриминацию по признакам расы и национальности. Данное положение в полной мере отвечало международно-правовым стандартам в области защиты прав и свобод человека.

В-третьих, в редакции ст. 74 УК 1960 г. отсутствовали квалифицирующие признаки преступления. Это в свою очередь говорит об отсутствии дифференцированной уголовной ответственности за нарушение национального и расового равноправия, которая имела место в УК 1926 г.

В-четвертых, изменено наказание за совершение рассматриваемого преступления. Совершение преступления, предусмотренного ст. 59.7 УК 1926 г., наказывалось лишением свободы на срок до двух лет, а при наличии отягчающих обстоятельств - лишением свободы не ниже двух лет с конфискацией всего или части имущества и даже высшей мерой наказания. В УК 1960 г. за совершение аналогичного преступления было предусмотрено наказание в виде лишение свободы на срок от шести месяцев до трех лет или ссылкой на срок от двух до пяти лет.

Аккумулируя изложенное, можно сделать вывод, что ст. 74 УК 1960 г. полностью отвечала положениям Конституции РСФСР 1937 г. Следует отметить, что именно в Конституции 1937 г. впервые было закреплено, что «всякая проповедь расовой или национальной исключительности или ненависти или пренебрежения» [7] карается законом (ч. 2 ст. 127).

В 1978 г. принимается новая Конституция РСФСР. В целом конституционные положения в рассматриваемой сфере повторяли положения аналогичных статей в предыдущей Конституции. Однако в ч. 1. ст. 32 Конституции 1978 г. закреплялся принцип равенства граждан перед законом независимо от происхождения, социального и имущественного положения, расовой и национальной принадлежности, пола, образования, отношения к религии, рода и характера занятий, места жительства и других обстоятельств чего не было в прежних конституциях. В ч. 2 утверждался принцип равенства граждан РСФСР во всех областях экономической, политической, социальной и культурной жизни. Еще одной новеллой Конституции 1978 г. было установление запрета на возбуждение вражды и ненависти в связи с религиозными верованиями (ст. 50).

За период действия УК 1960 г. нормы, регламентирующие ответственность в сфере противодействия экстремизму и терроризму, изменялись и дополнялись, а также вводились новые нормы.

Так, Законом РСФСР от 25 июля 1962 г. в УК [8]были введены ст. 88.1 и ст. 88.2, устанавлива- 
ющие ответственность за недонесение и укрывательство о государственных преступлениях соответственно. Данные нормы не содержали никаких новелл и были известны предыдущему УК и УК 1960 г. в первоначальной редакции. Так, в ст. 58.12 УК 1926 г. устанавливалась ответственность за аналогичные деяния: в ч. 1 - за укрывательство и пособничество за большинство контрреволюционных преступлений, в ч. 2 - за недонесение о достоверно известных предстоящих и совершенных таких преступлениях. В первоначальной редакции УК 1960 г. в ст. 18 «Укрывательство» и ст. 19 «Недонесение» ответственность за аналогичные деяния была возможна лишь в случаях, специально предусмотренных Особенной частью УК. В ст.ст. 189 и 190 главы восьмой «Преступления против правосудия» содержался перечень таких специально предусмотренных случаев. Сравнение содержания диспозиций ст. ст. 189 и 190 УК 1960 г. в первоначальной редакции с диспозициями вновь введенных ст. ст. 88.1 и 88.2 соответственно, позволяет сделать вывод, что перечень государственных преступлений, за укрывательство которых и недонесение о которых наступала уголовная ответственность, изменен не был. Результатом введения ст. ст. 88.1 и 88.2 в УК 1960 г. стало лишь «извлечение» из перечня преступлений, указанных в диспозициях ст. ст. 189 и 190, всех государственных преступлений и установление ответственности за их укрывательство, и недонесение о них в соответствующей главе УК.

Таким образом, законодатель использовал прежний подход в вопросе регламентации ответственности за недонесение и укрывательство соответствующих преступлений. Данное решение законодателя представляется более рациональным. Следует согласиться с мнением Н.С. Таганцева, что «с помещением отдельных случаев прикосновенности в соответствующие рубрики можно верно оценить как основания их наказуемости, так и характеристические признаки каждого типа» [9, с. 369].

8 апреля 1989 г. Президиумом Верховного Совета РСФСР принят Указ [10], внесший существенные изменения в уголовное законодательство в рассматриваемой сфере. Редакции ст. ст. 70 и 74 УК 1960 г. подверглись значительным изменениям, суть которых заключается в следующем:

В новой редакции диспозиции ст. 70 УК, ранее предусматривающей ответственность за антисоветскую пропаганду и агитацию, устанавливалась ответственность за «публичные призывы к насильственным свержению или изменению советского государственного и общественного строя, закрепленного Конституцией СССР, а также распространение с этой целью материалов такого содержания».

Редакция диспозиции ст. 74 УК 1960 г. стала выглядеть следующим образом «умышленные действия, направленные на возбуждение национальной или расовой вражды или розни, на унижение национальной чести и достоинства, а равно прямое или косвенное ограничение прав или установление прямых или косвенных преимуществ граждан в зависимости от их расовой или национальной принадлежности». Выделим отличительные особенности формулировки новой редакции ст. 74 УК 1960 г. в сравнении с предыдущей редакцией:

а) новеллой закона стало установление ответственности за действия, направленные на унижение национальной чести и достоинства;

б) выделены квалифицирующие признаки рассматриваемого преступления:

- действия, перечисленные в диспозиции ст. 74 УК 1960 г., соединенные с насилием, обманом или угрозами, а равно совершенные должностным лицом (ч. 2 ст. 74). Следует отметить, что законодательная формулировка данного квалифицирующего признака не лишена недостатков, так как его содержание не согласовано со спецификой признаков и конструкцией основного состава преступления. Представляется, что слово «действия» не в полном объеме охватывает смысл уголовноправовой нормы. Да, действительно, нельзя совершить деяния, перечисленные в диспозиции ст. 74, соединенные с насилием, обманом или угрозами, путем бездействия. Однако одна из форм объективной стороны рассматриваемого преступления, а именно, ограничение (прямое или косвенное) прав граждан, может выражаться и в бездействии (например, непринятие на работу), и совершено оно может быть должностным лицом. Если исходить из буквального толкования данной нормы, то в указанном примере бездействие должностного лица не охватывается ч. 2 ст. 74 УК 1960 г.

- Действия, предусмотренные ч. 1 и ч. 2 ст. 74 УК 1960 г., совершенные группой лиц либо повлекшие гибель людей или иные тяжкие последствия (ч. 3 ст. 74).

в) Диспозиция ст. 74 УК 1960 г. не содержит подробной характеристики объективной стороны преступления. Она была сформулирована, как и диспозиция ныне действующей ст. 282 УК РФ, таким образом, что любые действия, направленные 
на возбуждение национальной или расовой вражды или розни, а также на унижение национальной чести и достоинства, составляют объективную сторону преступления;

г) изменено наказание за совершение рассматриваемого преступления. Совершение преступления, предусмотренного ст. 74, в первоначальной редакции УК 1960 г. наказывалось лишением свободы на срок от шести месяцев до трех лет или ссылкой на срок от двух до пяти лет. В новой редакции ст. 74 за данное преступление предусматривалось наказание в виде лишения свободы на срок до трех лет или штрафа до двух тысяч рублей. Как видим, был исключен минимальный размер наказания в виде лишения свободы и изменен альтернативный вид наказания.

За квалифицированный вид данного преступления назначалось наказание в виде лишения свободы на срок до пяти лет или штраф до пяти тысяч рублей, а за особо квалифицированный безальтернативно лишение свободы на срок до десяти лет. В связи с отсутствием в первоначальной редакции ст. 74 УК 1960 г. квалифицирующих признаков данного преступления не представляется возможным сопоставить санкции рассматриваемых норм. Однако выделение квалифицированных видов позволяет сделать вывод, что законодатель усилил ответственность за рассматриваемое преступление. Вместе с тем нельзя признать, что наказание за основной состав преступления, предусмотренного ст. 74 УК, было ужесточено. Данный вывод следует из того, что в новой редакции санкции ч. 1 ст. 74 УК 1960 г., указан только максимальный срок наказания в виде лишения свободы. Соответственно минимальный срок лишения свободы за это преступление составляет три месяца (ст. 24 УК 1960 г.). Напомним, ранее минимальный размер наказания в виде лишения свободы за данное преступление был равен шести месяцам. Изложенное позволяет сделать вывод, что санкция рассматриваемой нормы изменилась в сторону смягчения наказания.

Следует отметить, что в 1992 г. в связи с принятием Закона «О внесении изменений в Уголовный кодекс РСФСР, связанных с порядком перерасчета штрафов», размер штрафов за совершение преступлений, предусмотренных ст. 74 УК 1960 г., был изменен.

В 1992 г. принят Закон РФ «О защите конституционных органов власти в Российской Федерации» [11], которым вновь была изменена редакция ст. 70 УК 1960 г. В ч. 1 ст. 70 устанавливалась ответствен- ность за «публичные призывы к насильственному изменению конституционного строя или захвату власти, а равно массовое распространение материалов, содержащих такие призывы»; в ч. 2 - за «те же действия, совершенные повторно либо организованной группой лиц»; в ч. 3 - за вышеуказанные действия, совершенные по заданию иностранных организаций или их представителей.

Дальнейшее развитие законодательства в рассматриваемой сфере произошло в 1993 г. В результате реформы [12] УК 1960 г. ст. 74 получает новое наименование - «Нарушение равноправия граждан по признаку расы, национальности или отношения к религии», и новую редакцию диспозиции. В соответствии с новой редакцией диспозиции в ст. 74 УК вновь криминализировано возбуждение религиозной вражды или розни. Данное положение полностью соответствовало ст. 50 Конституции РСФСР1978 г., устанавливающей запрет на возбуждение вражды и ненависти в связи с религиозными верованиями. Кроме того сфера применения ст. 74 УК 1960 г. была расширена уголовно-наказуемым деянием стало признаваться наряду с ограничением прав или установлением преимуществ по признакам расы и национальности также и ограничение прав или установление преимуществ по признаку отношения к религии.

Следующей из новелл редакции диспозиции ст. 74 УК 1960 г. стало расширение объективной стороны преступления за счет включения еще одного альтернативного способа совершения преступления, а именно, пропаганды исключительности либо неполноценности граждан по признаку отношения к религии, национальной или расовой принадлежности.

Необходимо отметить, что в соответствии с ныне действующим законодательством под преступлениями экстремистской направленности понимаются «преступления, совершенные по мотивам политической, идеологической, расовой, национальной или религиозной ненависти или вражды либо по мотивам ненависти или вражды в отношении какой-либо социальной группы» [13]. До 1993 г. в УК 1960 г. мотив ненависти или вражды по тем или признакам в качестве квалифицирующего признака в ряде статей Особенной части и в качестве одного из отягчающих обстоятельств выделен не был. И только 29 апреля 1993 г. Федеральным законом «О внесении изменений и дополнений в Уголовный кодекс РСФСР, Уголовно-процессуальный кодекс РСФСР и Исправительно-трудовой кодекс РСФСР» ст. 102 
«Умышленное убийство» УК была дополнена еще одним квалифицирующим признаком. В п. «м» ст. 102 УК устанавливалась ответственность за новый квалифицированный состав убийства - убийство, совершенное на почве национальной или расовой вражды или розни. До внесения данного дополнения в УК, убийства, совершенные по указанным мотивам, при отсутствии квалифицирующих признаков, перечисленных в ст. 102, подлежали квалификации по ст. 103 УК РСФСР. Представляется, что рассматриваемые мотивы совершения убийства расценивались как низменные побуждения и учитывались в качестве обстоятельства, отягчающего ответственность, при назначении наказания в соответствии с п. 3 ст. 39 УК 1960 г.

Необходимо отметить, что 2 апреля 1990 г. был принят Закон СССР «Об усилении ответственности за посягательство на национальное равноправие граждан и насильственное нарушение единства территорий Союза ССР» [14], который вводил в ст. 34 Основ уголовного законодательства Союза ССР и Союзных Республик новое отягчающее обстоятельство, которое суды должны были учитывать при назначении наказания, - «совершение преступления на почве национальной или расовой вражды или пренебрежения». Однако вследствие начавшейся уже в то время «войны законов» данная норма так и не была введена в УК [15, с. 29-33].

Очередные изменения законодательства в рассматриваемой сфере были внесены Федеральным законом от 1 июля 1994 г. № 10-Ф3 «О внесении изменений и дополнений в Уголовный кодекс РСФСР и Уголовно-процессуальный кодекс РСФСР». Данным законом в главу «Преступления против общественной безопасности, общественного порядка и здоровья населения» УК были введены две новые статьи - ст. 213.3 и ст. 213.4, в которых устанавливалась ответственность за терроризм и заведомо ложное сообщение об акте терроризма [16].

В соответствии со ст. 1 Федерального закона от 25 июля 2002 г. № 114-Ф3 «О противодействии экстремистской деятельности» под экстремизмом понимается также «воспрепятствование осуществлению гражданами их избирательных прав и права на участие в референдуме или нарушение тайны голосования» [17]. Следует отметить, что УК 1960 г. содержал ряд норм, регламентирующих ответственность за аналогичные деяния: ст. 132 «Воспрепятствование осуществлению избирательного права», ст. 133 «Подлог избирательных документов или неправильный подсчет голосов».
Продолжая анализ уголовно-правовых положений в рассматриваемой сфере, представляется необходимым отметить, что в главе четвертой «Нарушение правил об отделении церкви от государства» УК 1926 г., регламентировалась ответственность за преступления в сфере государственно-церковных отношений [6]. В УК 1960 г. глава с аналогичным или схожим названием отсутствовала. Однако в главе «Преступления против политических и трудовых прав граждан» УК 1960 г. имелась ст. 142, устанавливающая ответственность за нарушение законов об отделении церкви от государства и школы от церкви. Исключена данная статья была лишь в 1991 г. Также как и в УК 1926 г., в ст. 143 УК 1960 г. устанавливалась ответственность за воспрепятствование совершению религиозных обрядов. Причем формулировка диспозиции ст. 143 УК была полностью идентична аналогичной норме в УК 1926 г.

Таким образом, УК 1960 г. в первоначальной редакции не содержал никаких новелл в данной сфере. Однако в 1993 г. ст. 143 УК, получившая новое наименование - «Нарушение свободы совести и вероисповедания», была изложена в новой редакции. В ч. 1 устанавливалась ответственность за воспрепятствование законному осуществлению права на свободу совести и вероисповедания, в том числе совершению религиозных обрядов, сопряженное с насилием или угрозой насилия над личностью, а равно с уничтожением и повреждением имущества граждан, религиозных и общественных объединений или с угрозой совершения такого деяния; а в ч. 2 - за оскорбление чувств и убеждений граждан в связи с их отношением к религии с использованием в этих целях средств массовой информации или в иной публичной форме, а равно путем разрушения или повреждения культовых зданий, сооружений, иных предметов мировоззренческой символики, памятников, захоронений, нанесения на них оскорбительных надписей и изображений.

Анализируя развитие законодательства об ответственности за экстремизм и терроризм в период действия УК 1960 г., можно прийти к следующим выводам:

1) Началом нового этапа развития уголовного законодательства об ответственности за экстремизм и терроризм, стало принятие в 1958 году Закона СССР «Об уголовной ответственности за государственные преступления».

Во втором разделе Закона 1958 г. регламентировалась ответственность за разновидовые престу- 
пления. Указанное обстоятельство не способствовало выработке общего определения понятия иного государственного преступления. В связи с этим в юридической литературе советского периода отсутствует единое мнение по вопросу, что следует под таковым понимать. Необходимо отметить, что по этой же причине аналогичные сложности возникают и при выработке научного понятия «экстремизм (экстремистская деятельность)».

Анализ определений понятия «иное государственное преступление», выработанных наукой уголовного права, позволяет сделать вывод, что в большинстве своем ученые пытались раскрыть его содержание, исходя из непосредственного объекта преступлений, включенных в соответствующий раздел Закона 1958 г.

2) В УК 1960 г. появились новые нормы, регламентирующие ответственность за пропаганду войны (ст. 71) и террористический акт против представителя иностранного государства (ст. 67). Формулировка ст. 66, регламентирующей ответственность за террористический акт в УК РСФСР 1960 г., с точки зрения законодательной техники, была довольно четкой и полной. В ней довольно точно давалось понятие террористического акта, и были указаны признаки объективной и субъективной стороны преступления. В свою очередь это позволяло максимально исключить возможность применения при квалификации данного деяния смежных с ним норм.

В 1994 г. в УК были введены две новые статьи - ст. 213.3 и ст. 213.4, в которых устанавливалась ответственность за терроризм и заведомо ложное сообщение об акте терроризма.

3) Статья 74 УК, регламентирующая ответственность за посягательство на межнациональные отношения, в период действия УК 1960 г. трижды подвергалась изменениям - в 1989 г., 1992 г. и 1993 г.

В первоначальной редакции в ст. 74 УК 1960 г. впервые в истории уголовного законодательства России была установлена ответственность за дискриминацию по признакам расы и (или) национальности. Вместе с тем в описании объективной стороны данного преступления, не нашло отражение указание на агитацию и пропаганду, направленные к разжиганию религиозной вражды или розни, имевшее место в УК 1926 г. Несмотря на то, что ст. 74 УК отвечала положениям Конституции РСФСР 1937 г., данное решение законодателя можно оценить как определенный шаг назад. Исправлено оно было только в 1993 г. путем криминализации возбуждения религиозной вражды или розни. Данное положение полностью соответствовало ст. 50 Конституции РСФСР1978 г., устанавливающей запрет на возбуждение вражды и ненависти в связи с религиозными верованиями.

4) В 1993 г. впервые в истории уголовного законодательства России был специально выделен мотив национальной или расовой вражды или розни в качестве квалифицирующего признака преступления. В пункте «м» ст. 102 УК 1960 г. устанавливалась ответственность за новый квалифицированный состав убийства - убийство, совершенное на почве национальной или расовой вражды или розни.

\section{Библиография:}

1. Ермакова Л.Д. Особо опасные государственные преступления. Учебное пособие. М.: Издательство ВЮЗИ, $1982 .-$ С. 12.

2. Бешукова 3.М. Ответственность за экстремизм по Уголовному кодексу РСФСР 1922 года // Политика и Общество. - 2016. - № 3. - С. 395-401.

3. Бешукова 3.М. Понятие экстремизма: теоретико-методологический аспект // European Applied Sciences: challenges and solutions. 2nd International Scientific Conference. Stuttgart, Germany. C. 158-162.

4. Ермакова Л.Д. Иные государственные преступления: Общее понятие иных государственных преступлений. Преступления против национального и расового равноправия, против обороноспособности СССР. Учебное пособие. M., 1987. - C. 14.

5. Особо опасные государственные преступления / под общ. ред. В.И. Курляндского, М.П. Михайлова. М., 1963. - C. 110-111.

6. Бешукова 3.М. Правовые средства противодействия экстремизму в период действия некодифицированного уголовного законодательства Советской власти // Национальная безопасность / nota bene. - 2016. - № 1. - С. 149-159.

7. Конституция (Основной Закон) Российской Советской Федеративной Социалистической Республики (утверждена постановлением Чрезвычайного XVII Всероссийского Съезда Советов от 21 января 1937 г.). URL: http:/constitution. garant.ru/history/ussr-rsfsr/1937/

8. Уголовный кодекс РСФСР 1960 г. // СПС «Консультант плюс».

9. Таганцев Н.С. Русское уголовное право: Лекции. Часть Общая. Т. 1. М., 1994. - С. 369.

10. Указ Президиума Верховного Совета РСФСР от 8 апреля 1989 г. «О внесении изменений и дополнений в Уголовный и Уголовно-процессуальный кодексы РСФСР» // СПС «Консультант Плюс».

11. Закон РФ от 9 октября 1992 г. № 3618-1 «О защите конституционных органов власти в Российской Федерации» // СПС «Консультант Плюс». 
DOI: $10.7256 / 1811-9018.2016 .5 .18761$

При цитировании этой статьи сноска на dоі обязательна

История государства и права

12. Закон РФ от 27 августа 1993 г. № 5668-1 «О внесении изменений и дополнений в Уголовный кодекс РСФСР, Уголовнопроцессуальный кодекс РСФСР и Кодекс РСФСР об административных правонарушениях» // СПС «Консультант Плюс».

13. Уголовный кодекс Российской Федерации // СПС «Консультант Плюс».

14. Закон СССР от 2 апреля 1990 г. № 1403-1 «Об усилении ответственности за посягательства на национальное равноправие граждан и насильственное нарушение единства территории Союза ССР» // СПС «Консультант Плюс».

15. Волженкин Б.В. Из истории становления ст. 74 // Проблема ответственности за разжигание межнациональной розни. - М.: Мемориал, 1993. - С. 29-33.

16. Федеральный закон от 1 июля 1994 г. № 10-Ф3 «О внесении изменений и дополнений в Уголовный кодекс РСФСР и Уголовно-процессуальный кодекс РСФСР» // СПС «Консультант Плюс».

17. Федеральный закон от 25 июля 2002 г. № 114-ФЗ «О противодействии экстремистской деятельности» // СПС «Консультант плюс».

18. Бешукова 3.М. Ретроспективный анализ уголовного законодательства императорской России об ответственности за экстремизм (по Уложению о наказаниях уголовных и исправительных 1845 г. и Уголовному уложению 1903 г.) // Национальная безопасность / nota bene. - 2015. - 6. - С. 810 - 820.

\section{References (transliterated):}

1. Ermakova L.D. Osobo opasnye gosudarstvennye prestupleniya. Uchebnoe posobie. M.: Izdatel'stvo VYuZI, $1982 .-$ C. 12.

2. Beshukova Z.M. Otvetstvennost' za ekstremizm po Ugolovnomu kodeksu RSFSR 1922 goda // Politika i Obshchestvo. 2016. - № 3. - S. 395-401.

3. Beshukova Z.M. Ponyatie ekstremizma: teoretiko-metodologicheskii aspekt // European Applied Sciences: challenges and solutions. 2nd International Scientific Conference. Stuttgart, Germany. S. 158-162.

4. Ermakova L.D. Inye gosudarstvennye prestupleniya: Obshchee ponyatie inykh gosudarstvennykh prestuplenii. Prestupleniya protiv natsional'nogo i rasovogo ravnopraviya, protiv oboronosposobnosti SSSR. Uchebnoe posobie. M., 1987. - S. 14.

5. Beshukova Z.M. Pravovye sredstva protivodeistviya ekstremizmu v period deistviya nekodifitsirovannogo ugolovnogo zakonodatel'stva Sovetskoi vlasti // Natsional'naya bezopasnost' / nota bene. - 2016. - № 1. - S. 149-159.

6. Tagantsev N.S. Russkoe ugolovnoe pravo: Lektsii. Chast' Obshchaya. T. 1. M., 1994. - S. 369.

7. Volzhenkin B.V. Iz istorii stanovleniya st. 74 // Problema otvetstvennosti za razzhiganie mezhnatsional'noi rozni. - M.: Memorial, 1993. - S. 29-33.

8. Beshukova Z.M. Retrospektivnyi analiz ugolovnogo zakonodatel'stva imperatorskoi Rossii ob otvetstvennosti za ekstremizm (po Ulozheniyu o nakazaniyakh ugolovnykh i ispravitel'nykh 1845 g. i Ugolovnomu ulozheniyu 1903 g.) // Natsional'naya bezopasnost' / nota bene. -2015 . -6. - C. $810-820$. 